ŁUKASZ DOMINIAK

Instytut Politologii UMK

\title{
Problematyka seksualności w filozofii politycznej Michela Foucaulta
}

ichel Foucault poświęcił badaniom nad seksualnością swoje trzy ostatnie książki: Wole wiedzy ${ }^{1}$ Użytek z przyjemności ${ }^{2}$ oraz Troskę o siebie ${ }^{3}$. W edycji polskiej te trzy prace ukazały się razem, pod wspólnym tytułem Historia seksualności, w znakomitym tłumaczeniu Tadeusza Komendanta, Bogdana Banasiaka i Krzysztofa Matuszewskiego ${ }^{4}$.

Na temat seksualności Foucault wygłosił również dwa ważne wykłady, które następnie ukazały się drukiem: Seksualność $i$ władza przedstawiony na konferencji w Tokio 20 kwietnia 1978 roku $^{5}$, oraz Wykład z 17 marca 1976 zaprezentowany w College de France.

Badania nad seksualnością sytuują się w drugim, genealogicznym, okresie twórczości Foucaulta (jego początek to rok 1971, gdy wydany został Porzadek dyskursu $\left.{ }^{6}\right)$, co ma zasadniczy wpływ na charakter prowadzonych dociekań. O ile w przypadku koncepcji archeologicznej, której początkiem był 1961 rok (ukazuje się praca Historia szaleństwa $w$ dobie klasycyzmu'), Foucault

\footnotetext{
M. Foucault, La Volonté de savoir, Paris 1976.

Tenże, L'Usage des plaisirs, Paris 1984.

3 Tenże, Le Souci de soi, Paris 1984.

${ }^{4}$ Tenże, Historia seksualności, tłum. B. Banasiak, T. Komendant, K. Matuszewski, t. I, II, III, Warszawa 2000.

${ }^{5}$ Tenże, Sexualité et pouvoir (Sei to Kenryoku), “Gendai-shisô”, lipiec 1978, s. 58-77.

${ }^{6}$ Tenże, L'Ordre du discours, Paris 1971.

Tenże, Folie et déraison: Histoire de la folie à lâge classique, Paris 1961.
} 
opisywał czyste dyskursy, nie traktując ich jako znaku czegoś innego, lecz jako pole, na którym można dostrzec tworzenie się wiedzy uzyskującej status nauki, o tyle genealogia przenosi swe spojrzenie z (tylko) dyskursu na władzę i ciało ${ }^{8}$. Jednak należy przy tym pamiętać, że chociaż w okresie archeologicznym Foucault bada dyskursy jako systemy ludzkich wypowiedzi, to odnosi je również do spraw natury społecznej i politycznej. Od początku jego studiów historycznych mamy do czynienia z refleksją nad obecnością sił reglamentujących wyłanianie się dyskursów, czyli jeszcze nie nazwaną, lecz obecną władzą-wiedzą określającą wyłanianie się wypowiedzi ${ }^{9}$.

W centrum projektu genealogicznego znajduje się problematyka władzy. Wydobycie tej władzy na światło dzienne, zdemaskowanie jej i wyzwolenie ujarzmionej wiedzy jest zaś celem Foucaultowskiej genealogii. „Ujmując rzecz w dwóch słowach, mógłbym powiedzieć, że archeologia jest metodą analizy lokalnych dyskursów, a genealogia - taktyką, która, wychodząc od opisanych w ten sposób dyskursów, wyzwala wiedzę ujarzmioną i robi z niej użytek krytyczny"10.

W tym świetle projekt pomyślany jako historia seksualności, nie jest monografią dotyczącą dziejów seksu, lecz odkrywaniem relacji władzy i wiedzy, gdzie jak mówi Foucault: „chodzi zatem równocześnie o to, aby przyjmując inną teorię władzy stworzyć inny szablon historycznego rozszyfrowywania i aby przyglądając się nieco bliżej materiałowi historycznemu zbliżyć się stopniowo do innej koncepcji władzy; o to, by myśleć równocześnie o seksie bez prawa i o władzy bez króla" ${ }^{11}$.

Problem seksualności Michel Foucault rozpatruje w dwóch aspektach: 1. historycznym - w ramach którego odnosi się do tzw. tradycyjnej historii seksualności oraz dokonuje porównania charakteru zachodniego dyskursu seksualnego z dyskursem właściwym społeczeństwom Wschodu; 2. filozoficznym - a ściśle rzecz biorąc kratologicznym, w odniesieniu do którego rozpatruje seksualność jako wytwór i przekaźnik władzy-wiedzy.

\section{Aspekt historyczny}

Przez tradycyjną historię seksualności Foucault rozumie schemat i hipotezy, jakie napotyka się w trakcie śledzenia dziejów seksu na Zachodzie i które przedstawiają seksualność jako tabu, natomiast dziewiętnasto- i dwu-

\footnotetext{
${ }^{8}$ M. Kasztelan, Archeologia a genealogia wiedzy. Znaczenie Porządku dyskursu w twórczości Michela Foucaulta, „Edukacja Filozoficzna”, nr 36, 2003, s. 235-236.

9 Ł. Dominiak, Nowy Foucault, czyli analiza genealogiczna, „Dialogi Polityczne”, nr 2, 2004, s. 146.

${ }^{10}$ M. Foucault, Wykład z 7 stycznia 1976, w: tenże, Trzeba bronić społeczeństwa, tłum. M. Kowalska, Warszawa 1998, s. 23.

${ }^{11}$ Tenże, Wola wiedzy, dz.cyt., s. 83.
} 
dziestowieczne ruchy społeczne i polityczne oraz nurty w nauce (na czele z Freudem) jako wyzwolicieli łamiących odwieczny zakaz seksu, odwieczne „nie" władzy.

Dla określenia tych nurtów przyjmę tutaj figurę Prometeusza. Tytan Prometeusz stał się symbolem wyzwolenia rodzaju ludzkiego spod siły zła, metaforą buntu i uświadomienia. „Żyli jak mrówki w ciemnych jaskiniach, aż on [Prometeusz - Ł.D.] im pokazał, gdzie wschodzą gwiazdy i kędy zachodzą"12.

Prometejski (tradycyjny) schemat historii seksualności Zachodu przedstawiany jest w czterech głównych etapach:

1) Starożytność - w Grecji i w Rzymie seksualność była wolna i rozwijała się bez przeszkód. Władza nie ustanawiała zakazu. Co więcej, wykształcił się dyskurs przybierający formę artis eroticae, czyli swoistej sztuki erotycznej.

2) Chrześcijaństwo - seksualność zostaje obłożona pierwszym w historii wielkim zakazem. Władza organizowała się w trzech głównych obszarach: a) zakaz niemonogamicznego seksu, b) zakaz niereprodukcyjnego seksu, c) zakaz czerpania z seksu przyjemności.

3) Burżuazja - od wieku XVI moralność burżuazyjna zastąpiła i kontynuowała etykę chrześcijańską, podjęła temat ascetyzmu chrześcijańskiego na nowo i zaprowadziła jeszcze surowszą dyscyplinę.

4) Freud - od ostatnich lat XIX wieku za sprawą Zygmunta Freuda i opierających się na jego koncepcji ruchów społecznych, politycznych, kulturowych do dnia dzisiejszego mamy do czynienia ze zrzucaniem jarzma władzy z seksualności ${ }^{13}$.

\section{Seks zniewolony}

Historia milczenia seksu ma swój początek w chrześcijaństwie. Reguły monogamii, reprodukcji i wyłączenia przyjemności, w świetle tradycyjnego, prometejskiego schematu, zostały wprowadzone właśnie przez chrześcijaństwo. Chodzi o to, aby czerpać przyjemność seksualną w jak najmniejszym stopniu, korzystać z niej tylko po to, aby płodzić dzieci a prokreację odbywać tylko w małżeństwie ${ }^{14}$.

Podobnie rzecz się ma w kapitalistycznym i burżuazyjnym społeczeństwie. Wokół seksu zapada jeszcze większe milczenie. Para małżeńska stanowi prawo, wzór, normę i konstytuuje prawdę seksu.

\footnotetext{
${ }^{12}$ J. Parandowski, Mitologia, Poznań 1987, s. 37.

${ }^{13}$ M. Foucault, Seksualność i władza, w: tenże, Filozofia, historia, polityka. Wybór pism, tłum. D. Leszczyński, L. Rasiński, Warszawa-Wrocław 2000, s. 205-206.

${ }^{14}$ Tamże, s. 207.
} 
Z kolei wszelkie nielegalne przejawy seksualności, zgodnie z logiką kapitalistyczną, zostają wtrącone w sferę zysku i produkcji. Dom bez klamek i lupanar stały się przybytkami tolerancji. Powszechnie zabronione gesty i słowa podlegają tam wymianie po odpowiednich cenach ${ }^{15}$.

Jak twierdzi Foucault, nasilenie represji seksu od XVII wieku, łączyłoby się właśnie z rozwojem kapitalizmu. Seks został ujarzmiony, gdyż nie dał się pogodzić z powszechnym i wydajnym zatrudnieniem. Nie można było pozwolić, aby siła robocza zabawiała się innymi zajęciami niż praca. Należało zminimalizować utratę cennej energii, wyeliminować jałowe działania, przyjemności na boku ${ }^{16}$.

Podwaliny pod represję seksu położyło tu chrześcijaństwo a spotęgowało społeczeństwo burżuazyjne. Owo „nie” władzy, ten wielki zakaz miał służyć regulacji liczby ludności, reprodukcji siły roboczej, stworzeniu seksualności ekonomicznie użytecznej.

\section{Nadejście nowego seksu}

Zygmunt Freud tak charakteryzował pracę jaką ma wykonać psychoanaliza: „Za największe zagrożenie kultury uważa społeczeństwo wyzwolenie [podkreślenie - Ł.D.] się popędów seksualnych i ich powrót do pierwotnych celów. Społeczeństwo nie lubi więc, gdy się zwraca uwagę na tę drażliwą stronę jego powstawania, nie zależy mu na tym, by siła popędów seksualnych była uznana, a ich znaczenie stało się dla każdego jasne i wyraźne"17.

Tak psychoanaliza stała się obrazoburczą dyscypliną łamiącą powszechny zakaz i wyzwalającą seks. Jej rola polegałaby na usunięciu amnezji i niemoty seksu. Rozpoczęła rewolucyjny dyskurs o wolnym seksie wydartym władzy. Po pierwsze, przerwana została ta wielowiekowa zmowa milczenia na temat seksu. Po drugie, Freud argumentował, że tłumienie pożądania, popędów i seksu, czego wymaga życie w rozwiniętych społeczeństwach, $\mathrm{w}$ istocie uniemożliwia odczuwanie szczęścia ${ }^{18}$.

Tak oto mamy do czynienia z rozwojem prometejskich dyskursów konstytuujących nowy, lepszy seks. Skoro seksualność objęta jest zakazem milczenia, to sam fakt mówienia o niej ma charakter transgresywny i niesie z sobą posmak rewolucji. Ktoś, kto o seksie mówi bez skrępowania, kto nazywa rzeczy po imieniu, wychodzi poza zasięg władzy, narusza prawo, postuluje wolnośćc ${ }^{19}$.

\footnotetext{
${ }^{15}$ Tenże, Wola wiedzy, dz.cyt., s. 14.

${ }^{16}$ Tamże, s. 15.

${ }^{17}$ Z. Freud, Wstęp do psychoanalizy, tłum. S. Kempnerówna, Warszawa 1997, s. 56.

${ }^{18}$ N. Davies, Europa, tłum. E. Tabakowska, Kraków 2000, s. 915.

${ }^{19}$ M. Foucault, Wola wiedzy, dz.cyt., s. 16.
} 


\section{Władza seks zniewalająca}

\section{Hipoteza represji i prawny model władzy}

W tradycyjnej historii seksualności władza odciskająca się na seksie rozumiana jest jako system represyjny bądź system prawny. Foucault zwraca uwagę, że w teorii politycznej mamy do czynienia $\mathrm{z}$ dwoma wielkimi systemami analizowania władzy, które wykorzystane zostały w prometejskiej historii seksu.

System prawny znajdujemy już u filozofów XVIII wieku. Władza jest tu pierwotnym prawem, które człowiek odstępuje suwerenowi. $\mathrm{W}$ tym ujęciu władza jest prostym zakazem. Matrycą tego stosunku staje się kategoria umowy. Kiedy natomiast władza przekracza warunki tejże umowy, mamy do czynienia z uciskiem ${ }^{20}$.

System represyjny nie jest tożsamy z prawnym pojęciem władzy. Dotyczy on (choć nie tylko) wypowiedzi. W przypadku represji „należało najpierw wprowadzić ograniczenia na poziomie językowym, wziąć pod kontrolę jego swobodny obieg w dyskursie, usunąć $\mathrm{z}$ wypowiedzi i przytłumić słowa, które uobecniały się zbyt wyraźnie"21. Represja jest więc zakazem, ale zakazem różniącym się od zwykłego zakazu prawa karnego. „W odróżnieniu od zakazów prawa karnego: funkcjonuje ona jako skazanie na unicestwienie, ale też jako nakaz milczenia, potwierdzenie nieistnienia, i dlatego orzeka, że nie ma tu o czym mówić, czemukolwiek się przypatrywać, o czymkolwiek wiedzieć" ${ }^{22}$. Represja jest więc modelem władzy, która odrzuca, zakazuje, poddaje ekskluzji, pomija i obraca w niebyt. Jest cenzurą i niemotą seksu ${ }^{23}$.

W badaniach nad seksualnością Foucault łączy te oba systemy w jeden rodzaj władzy zwany ,jurydyczno-dyskursywnym”, który ma opisywać przebieg ujarzmiania seksu w historii. Jak mówi Foucault, w przypadku ,jurydyczno-dyskursywnego" systemu analizy władzy, mamy do czynienia z koncepcją, która „obejmuje zarówno tematykę represji, jak i teorię konstytutywnego prawa pragnienia. Innymi słowy, tym, co różni analizę podejmowaną w kategoriach represji instynktów od analizy w kategoriach prawa pragnienia, jest niewątpliwie sposób pojmowania natury i dynamiki popędów, a nie sposób pojmowania władzy. Obie analizy odwołują się do wspólnego przedstawienia władzy..." ${ }^{24}$.

\footnotetext{
${ }^{20}$ Tenże, Wykład z 7 stycznia 1976, dz.cyt., s. 29.

${ }^{21}$ Tenże, Wola wiedzy, dz.cyt., s. 22.

${ }^{22}$ Tamże, s. 14.

${ }^{23}$ Tenże, Seksualność $i$ władza, dz.cyt., s. 206.

${ }^{24}$ Tenże, Wola wiedzy, dz.cyt., s. 75.
} 


\section{System , jurydyczno-dyskursywny" władzy}

Postać władzy, która w myśl tradycyjnej historii seksualności miała wpływ na dzieje seksu, określana jest przez Foucaulta jako system ,jurydyczno-dyskursywny". Posiada on pięć głównych rysów, które opisują charakter władzy uciskającej seks:

1) Relacja negatywna - stosunek między władzą a seksem jest zawsze negatywny, czyli jest odrzuceniem, ekskluzją, odmową, zamaskowaniem. Władza zawsze mówi, tylko i wyłącznie, „nie”.

2) Instancja reguły - władza dyktuje seksowi prawo. W ten sposób poddaje seks podwójnemu uciskowi: ustala oś legalności i nielegalności oraz zakazu i przyzwolenia.

3) Cykl zakazu - władza stosuje taką oto prohibicję: seks nie może się ujawnić, gdyż w przeciwnym razie zostanie unicestwiony. Seks jest więc zmuszony do wyboru między dwoma nieistnieniami.

4) Logika cenzury - paradoksalna logika władzy nad seksem, który musi nie istnieć, nie ujawniać się, nie mówić.

5) Jedność urządzenia - władza nad seksem spełnia się jednakowo na wszystkich poziomach: globalnym i kapilarnym. W państwie i w rodzinie ${ }^{25}$.

Taką właśnie koncepcję władzy wykorzystuje, według Foucaulta, w swym założeniu tradycyjna historia seksualności.

\section{Krytyka genealogiczna}

\section{Zarzut co do metody}

Foucault zwraca uwagę, że pisanie historii seksualności posiłkujące się schematem władzy jako represji i zakazu prawnego, jak ma to miejsce w nurcie prometejskim, jest nieuzasadnione metodologicznie. Pytanie jakie stawia, brzmi: co przemawia za tym, aby pisząc historię seksualności, traktować w uprzywilejowany sposób koncepcję zakazu i zaprzeczenia? Wszak właśnie przez to aprioryczne przyjęcie koncepcji władzy jako represji, uzyskiwane są takie a nie inne wyniki badania. Tym samym Foucault stara się pokazać, iż równie słuszne, a może bardziej ciekawe i owocne byłoby uprawianie historii seksualności wychodzące od tego, co seksualność motywowało i do niej skłaniało, niż od tego, co jej zakazywało ${ }^{26}$.

\footnotetext{
${ }^{25}$ Tamże, s. 76-77.

${ }^{26}$ Tenże, Seksualność $i$ władza, dz.cyt., s. 206.
} 
Foucault zadaje w tym kontekście pytanie: czy mechanika władzy ze swej istoty należy do rzędu represji i czy zakaz, cenzura, stłumienie są prawdziwymi postaciami sprawowania władzy? ${ }^{27}$

Cel postulowanej przez Foucaulta metody badania seksualności jest więc odmienny. Nie chodzi o to, by analizować wiedzę o seksualności czy samą seksualność w kategoriach represji lub prawa, lecz w kategoriach władzy rozumianej nie jako zespół instytucji i aparatów zapewniających poddanie obywatela państwu i nie jako system panowania jednostki lub grupy nad resztą, lecz jako wielość stosunków sił immanentnych dziedzinie, w której się zawiązują ${ }^{28}$. Analiza taka zakładałaby więc przede wszystkim inną perspektywę władzy, nie jako wyłączenia (seksu), lecz jako włączenie i produktywność.

\section{Zarzut co do faktów}

Powszechnie przyjmowany schemat mówiący, że chrześcijaństwo nałożyło na wolny seks starożytnych trzy wielkie zakazy: 1) monogamii, 2) rozrodczości, 3) eliminacji przyjemności, nie jest prawdą historyczną.

Foucault za historykiem starożytnego Rzymu Paulem Veynem pokazuje, że te zasady istniały już w Rzymie przed pojawieniem się chrześcijaństwa. Były one zakorzenione w stoicyzmie i dotyczyły większości społeczeństwa. Poligamia i przyjemność pozamałżeńska były charakterystyczne tylko dla wąskiej elity, warstwy uprzywilejowanej, ludzi bogatych i rozwiązłych ${ }^{29}$.

Foucault zastanawia się również, czy aby na pewno represja seksu była historycznie oczywista? Czy pod narzucającym się schematem władzy jako represji, nie czai się inny wymiar seksualności? Jak twierdzi, w historii seksualności nie mamy do czynienia ze wzrostem represyjności, ze zmuszaniem seksu do milczenia, lecz z rozrostem dyskursów na jego temat, z nadzwyczajną i wyjątkową produktywnością wypowiedzi.

\section{Projekt Foucault}

\section{Nadwiedza i wyznanie}

Foucault twierdzi, że w społeczeństwie zachodnim mamy do czynienia nie tyle ze zmuszaniem seksu do milczenia, ile ze zwielokrotnieniem dyskursów o seksie. Pod płaszczykiem uładzonego słownictwa spotykamy instytucjonalną zachętę do mówienia. Teza Foucaulta jest więc znacząco radykalna. Jest niemalże przeciwna do tradycyjnej historii seksualności.

\footnotetext{
${ }^{27}$ Tenże, Wola wiedzy, dz.cyt., s. 19.

${ }^{28}$ Tamże, s. 83.

${ }^{29}$ Tenże, Seksualność $i$ władza, dz.cyt., s. 207.
} 
Teza ta głosi, że jesteśmy świadkami zjawiska nadwiedzy, czyli wiedzy o seksie w jakiś sposób zwielokrotnionej, intensywnej i ekstensywnej, nie na poziomie jednostek, lecz kultury i społeczeństwa. Kultura zachodnia została według niego dotknięta hiperrozwojem dyskursu seksualnego, teorii i nauki o seksualności ${ }^{30}$. Jak twierdzi Foucault, jest to zjawisko tak widoczne i przytłaczające swym ogromem, że nie można go po prostu pominąć, jak uczyniła to tradycyjna historia seksualności.

Nadwiedza ta miałaby swe źródła już w początkach chrześcijaństwa, które produkuje dyskursy moralne na temat seksu, a przede wszystkim wprowadza instytucję wyznania. Chodzi więc o sakramenty spowiedzi i pokuty.

$\mathrm{Z}$ jednej strony, w spowiedzi mamy proces wygładzania słownictwa, pytań okrężnych, odpowiedzi mglistych i jak najogólniejszych. $Z$ drugiej jednak, następuje ewolucja, która czyni z ciała źródło wszelkich grzechów i przesuwa akcent z samego aktu seksualnego na poryw pragnienia, myśli, wyobrażenia, upodobania. Tak oto pod osłoną oczyszczonego języka, seks zmuszony jest do mówienia i pozbawiony skrytości. Jak twierdzi Foucault, chrześcijaństwo postanowiło przepuścić wszystko, co ma związek z seksem, przez nieskończony młyn mówienia ${ }^{31}$.

Wiek XVIII przynosi jeszcze silniejszą nadprodukcję wiedzy na temat seksualności. Tym razem nie pod kątem moralności, lecz racjonalności. Pojawia się polityczna zachęta do mówienia $\mathrm{w}$ postaci analiz, kalkulacji, klasyfikacji, specyfikacji ilościowych i przyczynowych oraz studiów teoretycznych. Można tu wskazać na pojawienie się w XVIII wieku pojęcia „populacji” z przypisanymi jej cechami zależnymi od seksu: przyrostem naturalnym, śmiertelnością, długością życia, płodnością, stanem zdrowia, zachorowalnością etc. Rozrasta się ilość przepisów, ostrzeżeń, obserwacji, wskazówek lekarskich, przypadków klinicznych, schematów poprawy, planów idealnych instytucji, projektów architektonicznej kontroli ${ }^{32}$.

Religia, medycyna, pedagogika, prawo, edukacja, edukacja seksualna, psychiatria, psychologia wzięły seks $\mathrm{w}$ rachubę i wyprodukowały jego prawdziwy dyskurs. Określono osoby zabierające głos i wprowadzono przymus wyznania we wszystkich możliwych aspektach. „Od jednostkowego imperatywu, zmuszającego każdego człowieka do poddawania własnej seksualności ustawicznemu dyskursowi, aż po wielorakie mechanizmy, które w obrębie ekonomii, pedagogiki, medycyny, sądownictwa zachęcają, wyodrębniają, po-

\footnotetext{
${ }^{30}$ Tamże, s. 201-202.

${ }^{31}$ Tenże, Wola wiedzy, dz.cyt., s. 24-25.

${ }^{32}$ Tamże, s. 28-33.
} 
rządkują, instytucjonalizują mówienie o seksie, cywilizacja nasza osiągnęła i zorganizowała niebywałe rozgadanie" ${ }^{33}$.

Wyznanie, które było związane z chrześcijańską praktyką spowiedzi, wkroczyło na inne pola i zmieniło swoją specyfikę. Stało się badaniem, przeglądem oznak i symptomów, wywiadem, kwestionariuszem, hipnozą, wolnymi skojarzeniami. Przede wszystkim jednak stało się procedurą produkcji prawdy, prawdy o seksie i o człowieku. Powołało do życia nadwiedzę.

\section{Artis eroticae i scientia sexualis}

Poprzez instytucję wyznania społeczeństwa Zachodu wytwarzają wiedzę na temat seksu, która przybiera postać nauki. Jak zauważa Foucault, pierwszą rzeczą, jaką napotykamy, starając się badać zjawisko nadwiedzy, jest fakt, że produkowany na Zachodzie dyskurs seksualny niezwykle wcześnie przybrał postać nauki. Już od średniowiecza istniała w naszej kulturze spekulacja czym jest seksualność, pragnienie, pożądanie. Dyskurs ten uważał się za racjonalny i naukowy, gdyż odkrywał prawdę seksu ${ }^{34}$.

Jest to jednocześnie punkt różnicujący społeczeństwa Zachodu od niektórych społeczeństw Wschodu. O ile nasza kultura fundowała swoistą scientia sexualis, czyli naukę, o tyle Wschód stworzył artis eroticae, czyli sztukę.

Wschód wziął w rachubę rozkosz, która stała się przedmiotem poznania samym w sobie, a nie ze względu na inne cele: czy to prawdę czy prawo przyzwolenia i zakazu. Oto powstał dyskurs mający na celu doznawanie przyjemności, jej intensyfikację, przedłużenie. Stąd spotykany w kulturach Wschodu rozkwit poezji i prozy erotycznej. Wiele miejsca poświęca się zgłębianiu tajników seksu, wzmacniania doznań, nauki praktyki seksualnej. Wiedza ta jest tajemna, bynajmniej jednak nie z powodu ustanowienia tabu! Jej przekaz odbywa się z najwyższym namaszczeniem w relacji mistrz-uczeń. Najlepszym przykładem jest tu chyba hatha joga seksualna, która dzięki pracy z sobą i nad sobą prowadzi zarówno do rozwoju i opanowania ciała, połączenia energii księżycowej i słonecznej w mózgu, jak i do zwiększenia sprawności seksualnej oraz intensyfikacji przyjemności stosunku płciowego ${ }^{35}$.

Tymczasem nasza cywilizacja stworzyła dyskurs przeciwstawny sztuce erotycznej i sekretowi mistrzostwa: rozgadanie określone w instytucji wyznania. Tutaj też pojawia się pytanie podstawowe. Pytanie o powody. Dlaczego nasze społeczeństwo od zawsze pragnęło znać raczej prawdę o seksie, niż uczyć się przyjemności? Dlaczego powołało do życia właśnie naukę o seksie?

\footnotetext{
${ }^{33}$ Tamże, s. 36.

${ }^{34}$ Tenże, Seksualność $i$ władza, dz.cyt., s. 203.

${ }^{35}$ Zob. tenże, Wola wiedzy, dz.cyt., s. 56. Z. Lew-Starowicz, Erotyzm i techniki seksualne Wschodu, Warszawa 1991, s. 100-109.
} 


\section{Uwagi o chrześcijaństwie}

\section{Chrześcijaństwo jako nośnik władzy}

Powyżej zostało już powiedziane, iż chrześcijaństwo nie wprowadziło trzech wielkich zakazów co do seksu. Monogamia, reprodukcja i dyskwalifikacja przyjemności były już znane starożytnym Rzymianom i miały swoje źródło w filozofii stoicyzmu.

Czy wobec tego chrześcijaństwo nie niesie z sobą żadnej nowej jakości w odniesieniu do seksualności? Foucault twierdzi, że odegrało ono mimo to wielką rolę $\mathrm{w}$ dziejach seksu. Bynajmniej nie polegała ona jednak na wprowadzaniu nowych idei moralnych czy zakazów.

Chrześcijaństwo przyniosło $\mathrm{z}$ sobą nowe techniki władzy służące wpajaniu imperatywów moralnych. Historię seksualności na Zachodzie należałoby więc pisać od strony mechanizmów władzy, jakie wniosło ze sobą chrześcijaństwo (później również inne społeczne, polityczne, kulturowe procesy), nie zaś idei moralnych i etycznych zakazów ${ }^{36}$.

Pojawia się tu pytanie, jakie mechanizmy władzy wprowadziło chrześcijaństwo. Na pewno nie jest to zakaz. Gdyby bowiem seksualność była po prostu zakazana, represjonowana, to jak mogłoby dojść do powstania tak szerokiego dyskursu o seksie? Jak mogłoby dojść do pojawienia się zjawiska nadwiedzy?

Wydaje się raczej, że mechanizmy wprowadzone przez chrześcijaństwo jedynie (lub aż) nadały wartość już istniejącym zakazom. Te nowe techniki władzy mogą być rozumiane w kategoriach duszpasterstwa ${ }^{37}$.

\section{Gra pasterz-stado}

Władza pastoralna jest techniką władzy, której celem jest powiększenie dobrobytu poddanych za pomocą drobiazgowej i rozległej regulacji ich $z_{\text {zachowan }}^{38}$. Duszpasterstwo wprowadza do społeczeństwa kategorię jednostek, które odgrywają rolę pasterza i przewodnika w stosunku do innych, będących owcami bądź stadem. Jednostki te prowadzą stado przez życie od narodzin aż do śmierci ${ }^{39}$.

Władza pastoralna jest przede wszystkim związana z dobrem [podkreślenie - Ł.D.] poddanych, a nie $\mathrm{z}$ ich wolnością. Władza ta wymaga zdecydo-

\footnotetext{
${ }^{36}$ M. Foucault, Seksualność $i$ władza, dz.cyt., s. 207-208.

${ }^{37}$ Tamże, s. 208.

${ }^{38}$ B. Hindess, Filozofie władzy. Od Hobbesa do Foucaulta, tłum. D. Leszczyński, L. Rasiński,

Warszawa-Wrocław 1999, s. 124.

${ }^{39}$ M. Foucault, Seksualność $i$ władza, dz.cyt., s. 208.
} 
wanie czegoś więcej niż praw i towarzyszących im sankcji ${ }^{40}$. Ważną cechą władzy pastoralnej jest to, że nie odnosi się ona do terytorium, lecz do wielości jednostek. Rządzi się owcami, stadem. Stąd zasadniczą funkcją tej władzy nie będzie zwycięstwo, podbój, zdobycie bogactw, wzięcie niewolników (gdy władza odnosi się do terytorium, zwycięstwo jest zasadą podstawową). Mówiąc inaczej, funkcją władzy pastoralnej nie jest czynić zło wrogom, lecz dobro poddanym. Nie jest to władza tryumfująca, lecz dobroczynna ${ }^{41}$.

W przypadku władzy pastoralnej, stado istnieje tylko dzięki działaniom pasterza. Usunięcie pasterza powoduje rozpad stada. Z kolei pasterz opiekuje się stadem zarówno indywidualnie, jak i zbiorowo w zależności od potrzeb $^{42}$. Jest on w stanie dla dobra stada poświęcić życie. W tradycyjnej władzy mechanizm jest odwrotny. To obywatel poświęca się na rozkaz. Władza pastoralna jest więc władzą ofiarnąa ${ }^{43}$.

\section{Skutki władzy pastoralnej}

Po pierwsze, jako że władza pastoralna zakłada istnienie przewodnika, to każda jednostka zobowiązana jest dążyć do zbawienia. „Rola pasterza polega na zapewnieniu swemu stadu zbawienia" ${ }^{4}$. Po drugie, jako że władza pastoralna jest władzą indywidualną (zależnie od potrzeb), to zbawienie również staje się sprawą każdego z osobna. Innymi słowy, choć robi się wszystko dla zbawienia, to nie jest ono przedmiotem wyboru. Jednostka w świecie chrześcijańskim musi zostać zbawiona, w innym wypadku zostanie ukarana. W tym też kryje się sedno władzy przewodnika. Ma on prawo zobowiązać jednostkę do wszystkiego, co niezbędne dla zbawienia. Zbawienie jest obowiązkowe ${ }^{45}$.

Władza przewodnika osadza się również na fakcie, że jednostka nie może osiągnąć zbawienia sama. Można je osiągnąć tylko akceptując autorytet przewodnika. Tak oto przewodnik uzyskuje prawo oceny tego, co jest dobre, a co złe. Może osądzić, jak się rzeczy mają. Chrześcijaństwo wprowadzając grę pasterz-stado, włączyło nową formę analizy zachowania. Obok norm prawnych pojawiła się inna postać uznawania winnym, inny rodzaj skazywania. Przewodnik jest w istocie nadzorcą. Zapewnia ciągłą kontrolę ${ }^{46}$.

\footnotetext{
${ }^{40}$ B. Hindess, Filozofie władzy..., dz.cyt., s. 124-125.

${ }^{41}$ M. Foucault, Seksualność $i$ władza, dz.cyt., s. 209.

${ }^{42}$ B. Hindess, Filozofie władzy..., dz.cyt., s. 125.

${ }^{43}$ M. Foucault, Seksualność i władza, dz.cyt., s. 209.

${ }^{44}$ Tenże, „Omnes et singulatim”: przyczynek do krytyki politycznego rozumu, w: tenże, Filozofia, historia, polityka..., dz.cyt., s. 223.

${ }^{45}$ Tenże, Seksualność $i$ władza, dz.cyt., s. 210.

${ }^{46}$ Tamże, s. 210-211.
} 
Pasterz jako istota wyższej rangi uzyskał prawo narzucania swej woli jednostkom bez uzyskiwania ich zgody. Dzięki temu może on wymagać od stada działania bez względu na to, czy chce ono działać, czy nie. W tym tkwi duża różnica między władzą pastoralną a suwerenną, opartą na zgodzie ${ }^{47}$.

Władza pastoralna sytuuje się również poza, ściśle rozumianym, państwem. Przewodnik nie jest królem, suwerenem, głową państwa. Duszpasterstwo jest więc silnym ośrodkiem władzy politycznej znajdującym się poza państwem.

\section{Prawda (seksu) jako wynik działań władzy}

Wprowadzona przez chrześcijaństwo władza pastoralna wniosła ze sobą serię technik produkcji prawdy. Przewodnik chrześcijański miał prawo nauczać, co wpisywało go w tradycję dawnych mistrzów - filozofów. Naucza on prawdy, czyli Pisma, naucza moralności i przykazań kościelnych. Naucza jednak również w innym sensie. Aby wykonać swój obowiązek nauczania i przewodzenia, musi wiedzieć o wszystkim, co robi stado. Musi więc znać również od wewnątrz to, co dzieje się w duszy, w sercu poddanego. Poznanie wnętrza to niezbędny warunek dla sprawowania przewodnictwa ${ }^{48}$.

Owo poznanie wnętrza jednostek dokonuje się przez serię środków analizy, refleksji, wykrywania. Jednocześnie jednak sam chrześcijanin jest zobowiązany uciekać się do przewodnika w ramach praktyki wyznania. Musi on spowiadać się z tego, co dzieje się w jego duszy swojemu pasterzowi, który będzie z kolei zobowiązany do kierowania jego świadomością. Samo wyznanie wytworzy zaś rodzaj specyficznej prawdy, która nie była znana przewodnikowi, ale nie była też znana jednostce. Jest to prawda wyprodukowana dzięki badaniu świadomości i spowiedzi. Powstaje prawda, która rozwija się w kierunku duszy i świadomości, która jest więzią łączącą jednostkę z pasterzem ${ }^{49}$. „Związek zakazu i silnej zachęty do mówienia jest niezmienną cechą naszej kultury. Temat wyrzeczenia się ciała łączył się ze spowiedzią mnicha, który wyznawał opatowi wszystko, co zaprzątało jego myśli" ${ }^{50}$.

Tak oto Foucault ukazuje, jak prawda staje się produktem władzy. To pewien rodzaj, pewna modalność władzy powołuje do życia prawdę o duszy, o jednostce, prawdę jednostki o niej samej. Produkcja ta jest również produkcją tożsamości, produkcją ,ja".

\footnotetext{
${ }^{47}$ B. Hindess, Filozofie władzy..., dz.cyt., s. 125.

${ }^{48}$ M. Foucault, Seksualność $i$ władza, dz.cyt., s. 212.

${ }^{49}$ Tamże.

${ }^{50}$ Tenże, Techniki siebie, w: tenże, Filozofia, historia, polityka..., dz.cyt., s. 247.
} 


\section{Od policji do psychoanalizy}

\section{Władza pastoralna. Ponowne rozpatrzenie kwestii}

Jak twierdzi Foucault, najbardziej całościowe spełnienie konstrukcji władzy pastoralnej znalazło miejsce w teorii policji i kameralizmie rozwijających się w Europie w XVII i XVIII wieku. Teoria policji ilustruje odpowiedzialność za dobro stada.

Praktyki chrześcijańskiej spowiedzi, badania siebie, przewodnictwa można napotkać w wiekach późniejszych nie tylko w kościele, lecz również w urzędach państwowych, organizacjach charytatywnych i filantropijnych, $\mathrm{w}$ wielu rodzajach doradztwa, terapii, technik modyfikacji osobowości, edukacji ${ }^{51}$.

W XVIII wieku seks stał się sprawą policji, której zadaniem było zwiększenie indywidualnych i kolektywnych sił. Nie potępiano go w prosty sposób, lecz kierowano nim, włączano w systemy użyteczności, regulowano zgodnie z zasadą dobra ogółu. Seks poddano administracji, aby zwiększył wewnętrzną siłę państwa tkwiącą w zdolnościach i talentach. Wszystko to w imię dobra publicznego ${ }^{52}$. Urozmaicone szkolenie jednostek w sprawowaniu rządów nad sobą jest we władzy pastoralnej instrumentem rządzenia ich zachowaniem w permanentny sposób. Zdobyta przez pasterza wiedza o jednostkach daje mu nad nimi władzę.

Wraz z pojawieniem się problemu populacji, społeczeństwo zachodnie zdało sobie sprawę ze stawki, o jaką toczy się gra. Seks stał się centrum zagadnienia populacji, a ta z kolei miała decydować o sile państwa i społeczeństwa. Kraj bogaty musi być ludny i musi w odpowiedni sposób spożytkować swoją płeć. Włączenie się nowych dyskursów do tej gry podniosło wartość seksu. Medycyna włączyła go w sferę chorób nerwowych, psychiatria zaczęła doszukiwać się w nim etiologii chorób umysłowych, prawo wpisało go w schemat wykroczeń przeciw naturze ${ }^{53}$.

Mnożą się więc wokół seksu instancje kontroli i mechanizmy nadzoru: terapeutyka, pedagogika, medycyna, psychiatria etc. Władza powiela swoje przekaźniki i wpływy. Rozciąga sieć. Władza nie ma tu jednego ośrodka, buduje raczej swe naczynia włosowate. Jednocześnie działa poprzez rozciągnięcie swojego obiektu. Tworzy nowe klasyfikacje, wprowadza jednostki chorobowe i perwersje. Władza produkuje różnorodność seksu i wtapia ją w ciała, czyni z niej zasadę klasyfikacji i zrozumiałości. Wciela wiedzę w jednostki.

\footnotetext{
${ }^{51}$ B. Hindess, Filozofie władzy..., dz.cyt., s. 127.

${ }^{52}$ M. Foucault, Wola wiedzy, dz.cyt., s. 29.

${ }^{53}$ M. Foucault, Wola wiedzy, dz.cyt., s. 29-34.
} 
„Władza ta nie występuje pod postacią prawa, ani nie wywołuje następstw właściwych zakazowi. Przeciwnie, oparta jest na mnożeniu osobliwych przejawów seksualności. Nie wytycza granic seksualności, lecz rozciąga jej rozmaite formy, ścigając je nieskończoną penetracją. Nie wyłącza jej, lecz wtłacza w ciało jako zasadę klasyfikacji jednostek" ${ }^{54}$.

Wielorakie postacie seksualności, perwersje, występki przeciw naturze to wytwór działań władzy i środek, narzędzie jej sprawowania. Perwersja nie jest kpiną z władzy mówiącej „nie”, to jej skutek i sposób interwencji, w której chodzi o normalizację. Jak podkreśla Foucault: „Sade dał formułę erotyzmu właściwą społeczeństwu dyscyplinarnemu: społeczeństwu reglamentowanemu, anatomicznemu, zhierarchizowanemu, $\mathrm{z}$ jego starannie odmierzanym czasem, parcelacją przestrzeni, z jego powinnościami i przeciwnościami. Przyszedł czas, żeby i to społeczeństwo, i erotykę Sade’a porzucić" 55.

\section{Urządzenie seksualności}

Foucault pod pojęciem urządzenia seksualności rozumie mechanizm społeczny, za którego sprawą wiedza i praktyka seksualna rozpraszają się w społeczeństwie. Rozproszenie to należy traktować jako łączenie się wiedzy i praktyki seksualnej ze stosunkami politycznymi, ekonomicznymi, (ogólnie) władczymi w odrębne serie. Zwrócenie uwagi na owo rozproszenie pozwala badaczowi wyzwolić się spod wizji scentrowanej seksualności, która organizuje myślenie wokół źródeł, aksjomatów, zasad, sensów i przeprowadzić badanie seksualności jako wyniku działań władzy-wiedzy ${ }^{56}$.

Innymi słowy, urządzenie seksualności służy do produkcji dyskursów prawdziwościowych o seksie. Dzięki temu urządzeniu mogła pojawić się kategoria „seksualności” jako prawdy seksu.

Urządzenie seksualności można potraktować jako „ostateczny”, „finalny" efekt działań władzy i wiedzy. Zarówno opisywana tu gra pasterzstado, jak i dyscypliny, dominacje, czy najogólniej mówiąc władza rozumiana jako totalna struktura działań, w sferze seksu doprowadziły do powstania urządzenia seksualności. Wynikiem tego stało się urządzenie będące: 1) prawdą seksu, 2) narzędziem władzy, 3) skutkiem władzy.

Urządzenie seksualności mówi nam, że seksualność nie jest sprawą natury, jakąś naturalną daną, którą władza stara się poskromić. Nie jest też ona

\footnotetext{
${ }^{54}$ M. Foucault, Wola wiedzy, dz.cyt., s. 49.

${ }^{55}$ Tenże, Sade, kapral seksu, tłum. B. Banasiak, w: tenże, Powiedziane, napisane. Szaleństwo $i$ literatura, tłum. B. Banasiak, T. Komendant, M. Kwietniewska, A. Lewańska, M. P. Markowski, P. Pieniążek, Warszawa 1999, s. 271.

${ }^{56}$ Ch. C. Lemert, G. Gillan, Michel Foucault. Teoria spoteczna i transgresja, tłum. D. Leszczyński, L. Rasiński, Warszawa-Wrocław 1999, s. 169-170.
} 
mroczną dziedziną, którą stara się rozjaśnić wiedza. Seksualność to wynik produkcji. To nazwa, jaką powinniśmy nadać wyprodukowanemu historycznie urządzeniu, w którym stymulacja ciał, zwiększenie przyjemności, zachęta do mówienia, metody poznawcze, rozciągnięcie obszarów kontroli i oporów są wynikiem strategii władzy i wiedzy ${ }^{57}$.

Urządzenie to mówi nam, że seksualność jest historycznym produktem władzy-wiedzy. W wyniku chrześcijańskiego wyznania, a później burżuazyjnych instytucji władzy pastoralnej, w wyniku powołania dyscyplin, wspólna gra władzy i wiedzy stworzyła seksualność. Włączenie seksu w domenę medycyny, pedagogiki, prawa, psychiatrii, psychologii, biologii etc. spowodowało zróżnicowanie jego przejawów np. włączenie perwersji. Określona i stworzona została prawda seksu użytecznego politycznie i ekonomicznie, zwana „seksualnością”. Tak oto seksualność przedstawiana jest nam jako prawda o seksie. W rzeczywistości jest jednak tylko prawdą polityczną, wytworzonym przez władzę urządzeniem.

\section{Psychoanaliza jako wcielenie urządzenia seksualności}

Po pierwsze, widać teraz od razu, że obraz psychoanalizy jako Prometeusza wyzwalającego seks spod jarzma represyjnej władzy nie zdaje egzaminu. Psychoanaliza nie tylko niczego nie wyzwala, lecz sama staje się technologią władzy i wiedzy. Wszak to właśnie kozetka psychoanalityka jest współczesną inkarnacją konfesjonału. Oto mamy instytucję wyznania w najczystszej postaci. Nakaz mówienia, rozgadanie seksu. „Nie wyzwoliliśmy seksualności, ale - ściśle mówiąc - doprowadziliśmy ją do granicy: to granica naszej świadomości, bo seksualność dyktuje w końcu jedyną możliwą do przyjęcia przez naszą świadomość lekturę naszej nieświadomości; to granica prawa, bo seksualność okazuje się jedyną absolutnie uniwersalną treścią zakazu; to granica naszego języka - seksualność zarysowuje linią piany, pokąd da się sięgnąć na piasku milczenia. Nie dzięki niej zatem łączymy się z uporządkowanym i szczęśliwie świeckim (profane) światem zwierzęcym; seksualność jest raczej szczeliną, choć nie wokół nas, iżby nas izolować i wyróżniać, lecz by wrysować w nas granicę i wytknąć nas sobie samym jako granicę" ${ }^{" 58}$.

Po drugie, psychoanaliza staje się ostatnim wcieleniem, ostatnim wielkim zastosowaniem urządzenia seksualności. Jako ograniczona praktyka terapeutyczna, pełniła wobec innych procedur funkcję różnicującą w obrębie powszechnego urządzenia. Podczas, gdy organizuje się nagonkę na praktyki

\footnotetext{
${ }^{57}$ M. Foucault, Wola wiedzy, dz.cyt., s. 95.

${ }^{58}$ Tenże, Przedmowa do Transgresji, tłum. T. Komendant, w: tenże, Powiedziane, napisane..., dz.cyt., s. $47-48$.
} 
incestu wśród niższych klas, psychoanaliza staje się możliwością spełnienia kazirodczych popędów w dyskursie. Tak oto burżuazja uzyskuje przywilej silniejszego niż reszta doznawania rzeczy zakazanych. Dlatego też dla Foucaulta historia seksualności jest archeologią psychoanalizy. Sukces Freuda był możliwy nie dlatego, że działał on przeciw władzy i poza nią, lecz właśnie dlatego, że psychoanaliza rozwijała się wewnątrz urządzenia seksualności ${ }^{59}$.

\section{Władza nad seksem — władza nad człowiekiem}

\section{Ujarzmienie, czyli antyhumanizm Foucaulta}

Michel Foucault w swej historii urządzenia seksualności kolejny raz (po Nadzorować $i$ karać) podaje w wątpliwość ideę podmiotowości, niezależnego i autonomicznego ,ja”, które jako wynik gry sił panujących w danym społeczeństwie okazuje się mitem ${ }^{60}$. „Dziś można myśleć już tylko w pustce po zniknięciu człowieka"61.

Foucault jest autorem jednej z najbardziej wpływowych i znaczących koncepcji w ramach tzw. nurtu antyhumanistycznego. Jego dzieła prowadzą do radykalnej krytyki podmiotu ${ }^{62}$. Jak twierdzi Foucault, ,ja" jest wynikiem ujarzmienia. Odwraca on słynną metaforę i twierdzi, że dusza jest więzieniem ciała. Jak zauważa Tadeusz Płużyński, Foucault jest jednym z najbardziej znanych na Zachodzie proroków śmierci człowieka ${ }^{63}$. W jego studiach chodzi o „odwrócenie tradycyjnego problemu. Powinniśmy porzucić pytania typu: jak wolny podmiot może przeniknąć gęstwinę rzeczy i opatrzyć je znaczeniem, jak może ziścić swój zamiar ożywiając od wewnątrz prawa języka? $\mathrm{Na}$ ich miejsce powinny pojawić się inne: jak, w jakich warunkach i za pomocą jakich form coś takiego jak podmiot może pojawić się w porządku dyskursu? (...) Krótko mówiąc, chodzi o to, by pozbawić podmiot roli fundamentu i źródła i analizować go jako zmienną i złożoną funkcję dyskursu" ${ }^{64}$.

Władza, którą opisuje Foucault, to techniki służące do narzucania obowiązku, nadzorowania, kontrolowania zachowania jednostek, ich ruchów, rozmieszczenia, zdolności. Jej zasadniczym celem nie jest zakaz, lecz

\footnotetext{
${ }^{59}$ Tenże, Wola wiedzy, dz.cyt., s. 116.

${ }^{60} \mathrm{M}$. Łuczewski, Od tożsamości do tożsamości, w: Indywidualizm, wspólnotowość, polityka, M. N. Jakubowski, A. Szahaj, K. Abriszewski (red.), Toruń 2002, s. 128.

${ }^{61}$ M. Foucault, Człowiek ijego sobowtóry, tłum. T. Komendant, „Literatura na Świecie”, nr 6, 1988, s. 233.

${ }^{62}$ Przewodnik po wspótczesnej filozofii politycznej, R. E. Goodin, F. Pettit (red.), tłum. C. Cieśliński, M. Poręba, Warszawa 2002, s. 86.

${ }^{63}$ T. Płużyński, Prorocy śmierci człowieka, „Argumenty”, nr 6, 1977, s. 4.

${ }^{64}$ M. Foucault, Kim jest autor?, tłum. M. P. Markowski, w: tenże, Powiedziane, napisane..., dz.cyt., s. 218-219.
} 
zobowiązanie do zwielokrotnienia skuteczności jednostek, ich sił, wszystkiego tego, co pozwala używać ich w aparacie produkcyjnym społeczeństwa. Władza przygotowuje jednostki i umieszcza je tam, gdzie są potrzebne. Przyzwyczaja i przywiązuje ich ciała do specyficznej pracy, określonych ruchów. Władza jest więc produkcją zdolności, produkcją produktywności, produkcją jednostek ${ }^{65}$. „Toteż władza byłaby słaba i zapewne łatwo byłoby ją usunąć, gdyby sprowadzała się tylko do nadzorowania, śledzenia, zaskakiwania, zakazywania i karania; jednakże ona pobudza, tworzy, wytwarza; nie jest po prostu okiem i uchem; skłania do działania i mówienia" ${ }^{66}$.

W przypadku władzy pastoralnej, chrześcijaństwo ustanowiło pewną subiektywność, pewną świadomość siebie czujną na swe słabości i pokusy. Wywołało ono zwrot do wewnątrz, namysł, czuwanie nad sobą. Jak zauważa Foucault: „W przypadku monastycznych zapisów ćwiczeń duchowych chodzić będzie o przepędzenie z wnętrza duszy najbardziej ukrytych poruszeń po to tylko, by się od nich wyzwolic" ${ }^{67}$. Władza pastoralna była jednocześnie powołaniem wiedzy, wiedzy jednostek, wiedzy o jednostkach, wiedzy jednostek o nich samych. Seksualność stała się tutaj więzią łączącą ludzi ze swą tożsamością pod postacią subiektywności. W urządzeniu seksualnym zwielokrotniono dyskurs naukowy, który uporządkował nasze zachowanie. Władza narzuciła ludziom pewną liczbę zachowań, które produkują, indywidualizują jednostkę. Seksualność stała się produkowanym zespołem zachowań i wiedzy, które łączą ludzi z (produkowaną i narzucaną) tożsamością przybierającą pozór subiektywności.

Instytucja wyznania produkująca wypowiedź, zawsze prowadzi do wewnętrznych przemian osobnika mówiącego: uniewinnia go, odkupuje, oczyszcza, zdejmuje odium winy, uwalnia. Wyznanie żąda od seksu, aby powiedział prawdę, prawdę o sobie, ale przede wszystkim prawdę o nas, głęboko ukrytą prawdę o nas samych. „W głębi płci kryje się prawda” ${ }^{68}$. Z tego żądania wyłoniła się wiedza o podmiocie, o ,ja”. Podstawowe pytanie, jakie stawiane jest seksowi brzmi: czym jesteśmy? ${ }^{69}$

Intensywna produkcja dyskursu prawdziwościowego o seksie jest równocześnie produkcją zachowań, wiedzy o jednostkach, subiektywnej wiedzy i samowiedzy jednostek, jest produkcją naszego „ja”. Opisywana przez Foucaulta władza „zagraża samej możliwości życia - czy też raczej możliwości

\footnotetext{
${ }^{65}$ Tenże, Seksualność i władza, dz.cyt., s. 215-218.

${ }^{66}$ Tenże, Żywoty ludzi niegodziwych, tłum. P. Pieniążek, w: tenże, Powiedziane, napisane..., dz.cyt., s. 290.

${ }^{67}$ Tenże, Sobapisanie, tłum. M. P. Markowski, w: tamże, s. 319.

${ }^{68}$ Tenże, Prawdziwa płeć, tłum. Ariadna Lewańska, w: tamże, s. 296.

${ }^{69}$ Tenże, Wola wiedzy, dz.cyt., s. 60-72.
} 
życia jednostki" ${ }^{\prime \prime}$. Dlatego też dusza, ,ja” jest wynikiem ujarzmienia. Jak mówi Foucault: „Ten podmiot właśnie - który jest «Tym-właśnie» - został wyłączony"11.

\section{Podsumowanie}

Michel Foucault pisząc historię seksualności chce „dokopać się” do, funkcjonujących na głębszych poziomach społeczeństwa, mechanizmów władzy. Jego historia seksualności jest więc w swej istocie genealogią władzy-wiedzy.

Przyjmuje on przy tym założenie (i udowadnia je), że w świecie, w którym władza jest wszechobecna, nie ma miejsca dla danego z góry podmiotu. Nie ma tu miejsca dla podmiotu - transcendensu, jest on bowiem wynikiem gry sił i stosunków władzy. Jak zauważa Tadeusz Komendant, wynalazek Krytyki czystego rozumu zostaje zastąpiony „śmiercią człowieka”. Foucault wydaje wojnę wszelkiej wewnętrzności, gdyż, jak twierdzi, podmiot i dusza to ujarzmienie ciała.

W swej historii seksualności opisuje on urządzenie seksualności, które produkuje duszę. "Ja” bierze się z ujarzmienia. Należy więc rozbić mury więzienia i wyzwolić ciało. Wyzwolenie to nie może jednak przyjść z „zewnętrza" władzy, gdyż jest ona totalną strukturą działań. Wyzwolenie to akceptacja władzy jako gry między wolnościami i wydanie wojny wszelkiej dominacji. „Krytycznej ontologii nas samych nie należy z pewnością traktować jako teorii, doktryny, ani też jako stałego zbioru gromadzonej wiedzy; należy pojmować ją jako postawę, ethos, filozoficzne życie, gdzie krytyka tego, czym jesteśmy, jest zarazem historyczną analizą narzuconych nam granic i próbą ich przekroczenia"72. Jak mówi Foucault, zadanie filozofa polega na kwestionowaniu wszystkich form dominacji i wynika z sokratejskiego imperatywu: ugruntuj swoją wolność poprzez panowanie nad sobą.

Ł U K A S Z D O M I N I A K

\footnotetext{
${ }^{70}$ M. Jay, Granice doświadczenia granicznego: Bataille i Foucault, tłum. M. Kwiek, w: „Nie pytajcie mnie kim jestem...” Michel Foucault dzisiaj, M. Kwiek (red.), Poznań 1998, s. 43.

${ }^{71}$ M. Foucault, Las Meninas, tłum. A.Tatarkiewicz, „Studia Estetyczne”, t. 8, 1971, s. 234.

${ }^{72}$ Tenże, Czym jest Oświecenie?, w: tenże, Filozofia, historia, polityka..., dz.cyt., s. 293.
} 


\section{The problem of sexuality in Michel Foucault's political philosophy}

In his history of sexuality Michel Foucault searches for those mechanisms of power that exist on a deeper social levels. Thus this history becomes in fact a genealogy of power-knowledge.

Foucault describes the apparatus of sexuality. He considers sexuality as a discursive-institutional formation. Apparatus of sexuality produces sex. The West developed a scientia sexualis, that aims at discovering the truth about sex and at creating certain kind or certain practices of sexual behaviour. Sexuality is essentially organised around forms of power-knowledge. Those forms had been developing historically from the institution of confession to contemporary psychiatry or sexuology; from such divisions as sin-purity to normal and pathological. So, sexuality is not inchoate level of experience existing outside the discourse but is a product of this discourse, product of power-knowledge. Foucault distinguishes two areas, two ways of acting of power-knowledge: disciplines and biopolitics of population.

The analysis of the apparatus of sexuality implies a general conception of power and according to Foucault power has been immanent for the social structure since the Classical Ages (when human science emerged) and in an unbreakable union with knowledge. „No power is exercised without the extraction, appropriation, distribution or retention of knowledge. At this level, we do not have knowledge on the one hand and society on the other, or science and state; we have the basic forms of «power-knowledge»".

He assumes (and proves) that there is no place for a human subject in the world of ubiquity of power - such a human is a result of the fight of powers. 